\title{
Lab Attendance and Academic Performance
}

\author{
Kirk Adair and Omari H. Swinton \\ Department of Economics, Howard University, Washington, DC, USA \\ Correspondence should be addressed to Kirk Adair, kadair@howard.edu
}

Received 26 March 2012; Accepted 2 May 2012

Academic Editors: M. Brynin, K. Capps, M. F. Cerda, and H.-C. Lin

Copyright ( $) 2012$ K. Adair and O. H. Swinton. This is an open access article distributed under the Creative Commons Attribution License, which permits unrestricted use, distribution, and reproduction in any medium, provided the original work is properly cited.

\begin{abstract}
The benefits from attendance of lectures have been established in the literature. This paper focuses on attendance not of the lecture, but of smaller labs. These labs are 50 minutes one-day-a-week sessions to emphasis material covered during lecture. Using a 200student Principles of Economics class that covers microeconomics with six different labs, we investigate the effect of lab attendance on exam performance by taking into account individual characteristics. We find that lab attendance benefits the student in overall exam performance.
\end{abstract}

\section{Introduction}

Many studies have been done on absenteeism and how it affects student performance. The convention in the academia is that poor class attendance negatively affects final grades. The traditional approach to university instruction is largely based on physical attendance and exam performance. Studies have shown that attendance does matter for academic performance (see e.g., Durden and Ellis [1], Devadoss and Foltz [2], Romer [3], Stanca [4], Marburger [5], Dobkin, R. Gil, and J. Marion [6], and Marburger [7]). This evidence has led to mandatory attendance in some undergraduate courses.

However, obtaining an accurate measure of attendance is very difficult in large classes. As a result, many large lecture classes have recitations or lab instructions in smaller groups. It is our belief that this translates into attendance of smaller laboratory classes that are equally important to the lecture. However, it is unknown whether these smaller labs help improve student performance. We will answer whether these labs give students the same benefits as lecture attendance in smaller classes by using observations on the performance of about 200 Principles of Economics students on several tests and their attendance levels in labs. By using information that proxies for ability, such as high school Grade Point Average (GPA), college GPA, and Scholastic Aptitude Test (SAT) scores, we find that lab attendance has a positive and significant effect on test scores.
We take the liberty to give a brief introduction to the American educational system. International students who come to the United States may wonder about their American classmates' prior education. The structures and procedures at American universities differ somewhat from other systems, such as the British model. The admission procedure into a typical American University or college is based on several criteria, including a student's high school course of study, high school (GPA), participation in extracurricular activities, SAT or American college testing (ACT) exam scores, a written essay, and possibly a personal interview.

A GPA is a quantitative figure representing a student's accumulated grades. Each letter grade is assigned a number of points: $\mathrm{A}=4$ points, $\mathrm{B}=3, \mathrm{C}=2, \mathrm{D}=1$ and $\mathrm{F}=0$ points. A GPA is calculated by adding all the points earned for each course grade and dividing the total points by the total number of courses taken. For example, a GPA of 3.0 is a " $\mathrm{B}$ " average for all the courses taken. Most students in the United States take the SAT Reasoning Test or the ACT during their final year of high school. Each university sets a minimum SAT or ACT score that a student must achieve in order to gain admission. These are standardized quantitative examinations. The SAT tests critical reading, mathematics, and writing skills. The ACT tests English, mathematics, reading, and science reasoning and includes an optional writing test.

University students pursuing a Bachelor's degree are called "undergraduates," whereas students pursuing a 
TABLE 1: Descriptive statistics.

\begin{tabular}{lccccc}
\hline Variable & Obs & Mean & Std.dev & Min & Max \\
\hline $\begin{array}{l}\text { Age of student } \\
\text { Age of student }\end{array}$ & 196 & 20.27 & 1.38 & 18.34 & 31.33 \\
$\begin{array}{l}\text { Squared } \\
\text { SAT }\end{array}$ & 196 & 412.86 & 63.52 & 336.29 & 981.5 \\
$\begin{array}{l}\text { Fall 2008 term } \\
\text { Grade point }\end{array}$ & 187 & 1039.41 & 117 & 600 & 1440 \\
$\begin{array}{l}\text { Average } \\
\text { Spring 2009 }\end{array}$ & 192 & 2.79 & 0.73 & 0 & 4 \\
$\begin{array}{l}\text { Hours attempted } \\
\text { Students live on }\end{array}$ & 196 & 16.06 & 2.06 & 9 & 21 \\
$\begin{array}{l}\text { campus } \\
\text { Freshman } \\
\text { students }\end{array}$ & 196 & 0.39 & 0.49 & 0 & 1 \\
$\begin{array}{l}\text { Sophomore } \\
\text { students }\end{array}$ & 79 & & & & \\
$\begin{array}{l}\text { Junior } \\
\text { students }\end{array}$ & 87 & & & & \\
$\begin{array}{l}\text { Senior } \\
\text { students }\end{array}$ & 26 & & & & \\
\hline
\end{tabular}

Master's or Doctoral degree are called "graduate students." Most universities give undergraduate students a liberal education, which means students are required to take courses across several disciplines before they specialize in a major field of study. Graduate and professional (such as medicine or law) programs are specialized. At the university level, most courses are only one semester long. Each course is assigned a number of credit hours. Credit hours are usually based on how much time is spent in class each week. Most courses are 3 credits. However, some courses may be 1, 2, 4, or 5 credits. All degree programs require students to complete a minimum number of credit hours before graduation. Most Bachelor's degree programs in the United States do not require students to write a final thesis (The American Education System, Editorial provided by Susan E. Hume, Ph.D., Assistant Professor, Department of Geography, Southern Illinois University Edwardsville, http://www.internationalstudentguidetotheusa.com/articles/ american_education_system.php).

There are 18 million American college students, and that number is expected to increase by 2 million over the next eight years, as the value of a college degree continues to climb "“Monstrous class sizes are unavoidable at colleges: Nobel Prize-winning prof calls for reform, says huge classes cause damage." MSNBC. MSNBC. 24 November 2007. Web 10 February 2011 http://www.msnbc.msn.com/id/21951104/ ns/us_news-education". To get his or her through their coursework, monstrous class sizes are unavoidable. That does not have to be a bad thing. At their best, giant classes can be effective and inspiring - a way to get the best teachers in front of the most students. But according to Carl Wieman, who won the 2001 Nobel Prize as a physicist at Colorado, "such successes are rare".
TABLE 2: Distribution of lab attendance.

\begin{tabular}{lccc}
\hline $\begin{array}{l}\text { Number of labs } \\
\text { attended }\end{array}$ & $\begin{array}{c}\text { Lab attendance } \\
\text { before Exam 1 } \\
\text { (only 2 labs } \\
\text { offered) }\end{array}$ & $\begin{array}{c}\text { Lab attendance } \\
\text { after Exam 1 } \\
\text { but before } \\
\text { Exam 2 }\end{array}$ & $\begin{array}{c}\text { Lab attendance } \\
\text { after Exam 2 } \\
\text { but before } \\
\text { Exam 3 }\end{array}$ \\
\hline 0 & 8 & 4 & 6 \\
1 & 19 & 7 & 5 \\
2 & 73 & 15 & 10 \\
3 & & 36 & 28 \\
4 & & 38 & 51 \\
\hline
\end{tabular}

TABLe 3: Summary statistics Exam Grades.

\begin{tabular}{lccccc}
\hline Variable & Obs & Mean & Std. dev. & Min & Max \\
\hline Exam 1 & 190 & 64.17 & 17.33 & 12.00 & 100.00 \\
Exam 2 & 188 & 54.26 & 16.28 & 22.00 & 94.00 \\
Exam 3 & 186 & 70.31 & 13.96 & 36.00 & 100.00 \\
\hline
\end{tabular}

TABle 4: Summary statistics (means) by homework, quizzes, reports and in-lab activity.

\begin{tabular}{lccccc}
\hline Variable & Obs & Mean & Std. Dev. & Min & Max \\
\hline Homework 1 & 190 & 7.33 & 3.56 & 0.00 & 10.00 \\
Quiz 1 & 190 & 3.87 & 3.17 & 0.00 & 10.00 \\
Report 1 & 190 & 6.23 & 3.97 & 0.00 & 10.00 \\
In-lab activity 1 & 190 & 7.08 & 4.53 & 0.00 & 10.00 \\
\hline Homework 2 & 188 & 6.02 & 3.86 & 0.00 & 10.00 \\
Quiz 2 & 188 & 4.16 & 3.70 & 0.00 & 10.00 \\
Report 2 & 188 & 8.01 & 3.43 & 0.00 & 10.00 \\
In-lab activity 2 & 188 & 7.66 & 4.25 & 0.00 & 10.00 \\
\hline Homework 3 & 186 & 5.20 & 2.45 & 0.00 & 10.00 \\
Quiz 3 & 186 & 3.24 & 2.38 & 0.00 & 10.00 \\
Report 3 & 186 & 6.85 & 3.81 & 0.00 & 10.00 \\
In-lab activity 3 & 186 & 6.92 & 4.08 & 0.00 & 10.00 \\
\hline
\end{tabular}

The National Center for Academic Transformation or NCAT, estimates that the 25 most common college coursesin subjects like Economics, English, Psychology, and the Sciences-account for 35 percent of four-year college enrollment nationally. That means a lot of people are taking a relative handful of courses. Because of this fact, our paper provides a useful contribution to this area of research.

\section{Literature Review}

Many studies find that attendance improves student exam performance. Romer [3] raises the question of whether class attendance should be mandatory in college economics courses. More specifically, larger classes tend to have higher absenteeism than smaller classes, and there is a strong correlation between the quality of instruction and absenteeism. Chen and Lin [8] find that class attendance has a positive and significant impact on college students' exam performance. Marburger [5] shows that student performance is inversely correlated with absenteeism. The study suggests that this 
TABLE 5: Determinants of academic performance: estimates on lab attendance and lab instructor.

\begin{tabular}{|c|c|c|c|c|c|c|}
\hline Variables & $\begin{array}{l}\text { The 1st } \\
\text { Exam }\end{array}$ & $\begin{array}{l}\text { The 2nd } \\
\text { Exam }\end{array}$ & $\begin{array}{l}\text { The 3rd } \\
\text { Exam }\end{array}$ & $\begin{array}{l}\text { The 1st } \\
\text { Exam }\end{array}$ & $\begin{array}{l}\text { The 2nd } \\
\text { Exam }\end{array}$ & $\begin{array}{l}\text { The 3rd } \\
\text { Exam }\end{array}$ \\
\hline Lab attendance before Exam 1 & $\begin{array}{l}4.15^{* *} \\
(1.97)\end{array}$ & & & $\begin{array}{l}4.27 * * \\
(1.97)\end{array}$ & & \\
\hline $\begin{array}{l}\text { Lab attendance after Exam } 1 \text { but } \\
\text { before Exam } 2\end{array}$ & & $\begin{array}{c}3.69^{* * *} \\
(1.04)\end{array}$ & & & $\begin{array}{c}3.75^{* * *} \\
(1.06)\end{array}$ & \\
\hline $\begin{array}{l}\text { Lab attendance after Exam } 2 \text { but } \\
\text { before Exam } 3\end{array}$ & & & $\begin{array}{c}3.36^{* * *} \\
(0.87)\end{array}$ & & & $\begin{array}{c}3.36^{* * *} \\
(0.88)\end{array}$ \\
\hline Lab instructor A & & & & $\begin{array}{c}-2.8 \\
(3.13)\end{array}$ & $\begin{array}{c}1.05 \\
(2.96)\end{array}$ & $\begin{array}{l}-0.95 \\
(2.51)\end{array}$ \\
\hline Lab instructor B & & & & $\begin{array}{c}-5.57^{*} \\
(3.17)\end{array}$ & $\begin{array}{l}1.16 \\
(2.95)\end{array}$ & $\begin{array}{l}-0.44 \\
(2.54)\end{array}$ \\
\hline Constant & $\begin{array}{c}57.36^{* * *} \\
(3.47)\end{array}$ & $\begin{array}{c}43.39^{* * *} \\
(3.27)\end{array}$ & $\begin{array}{c}59.75^{* * *} \\
(2.91)\end{array}$ & $\begin{array}{c}60.17^{* * *} \\
(3.92)\end{array}$ & $\begin{array}{l}42.40^{* * *} \\
(4.05)\end{array}$ & $\begin{array}{c}60.25^{* * *} \\
(3.45)\end{array}$ \\
\hline Observations & 190 & 188 & 186 & 190 & 188 & 186 \\
\hline$R$-squared & 0.023 & 0.064 & 0.075 & 0.039 & 0.065 & 0.076 \\
\hline
\end{tabular}

Standard errors in brackets. ${ }^{* * *} P<0.01,{ }^{* *} P<0.05,{ }^{*} P<0.1$.

enforced mandatory attendance policy significantly reduces absenteeism and improves exam performance.

In a another study by Hollister [9] which cited three different studies, Turner, K.E. J Chem. Educ 1990, Deal, W.J.J Coll Sci. Teach 1984 and St. John, E. unpublished paper. Academic Support Services, U.C. Irvine, 1989 produced conflicting conclusions. Turner and St. John report that after accounting for varying math and verbal abilities increased workshop attendance is associated with higher final course scores. Deal, however, reported that the grade improvement was insignificant; however, he had a small sample size; nevertheless, he acknowledges that the significant level might be improved if the workshops were more extensive.

These papers use data sets that focus on class sizes. They do not address the problems that arise from not being able to take attendance. In large classes, it is nearly impossible to take attendance. Our belief is that regular attendance of labs is important in improving outcomes. We measure the attendance in our smaller lab classes to validate our hypothesis that lab attendance does matter.

\section{Data}

The data for this study were collected by looking at the lab attendance records and exams scores of 196 students enrolled in a Principles of Economics II class, which covered microeconomics for the spring 2009 semester. The course was taught over 16 weeks in the spring semester, and students earned 3 credit hours. While this course is a major requirement for economics students, it is also required of students in many disciplines. This lecture was held in a large auditorium. Lecture notes were posted online via Blackboard. This allowed all students access to the lecture notes at all times (Blackboard Course Portal data was not available for this paper). The course was structured such that there were three lectures every week with each lasting 50 minutes. The students selected one of six separate mandatory lab classes. Students had identical homework, quizzes, and in-lab assignments even though the work was done in different labs. The mandatory labs were held in different classrooms with about 31 students each. The students were allowed to pick the lab that fits their schedule with a lab everyday of the week except Sunday unless it was full. Students also could utilize office hours with the lab instructor or the lecture instructor at the students' discretion. Lectures were the primary means of instruction for the class. Students were given reading assignments, and the instructor randomly gave quizzes on these assignments during the lab periods throughout the semester to encourage studying and participation.

The labs were meant to supplement the class to provide individual attention for the student. The lab class was an attempt to involve students in active learning. During the labs, attendance was taken and homework and reports were collected, and periodically 20 -minute quizzes were given at the beginning of the lab class. There was also an in-lab activity that was given to encourage lab attendance. (The same materials was covered and taught in all the lab sessions).

The entire class consisted of four freshmen, seventy-nine sophomores, eighty-seven juniors, and twenty-six seniors with an average age of 20 years old. The average SAT score was 1039. (The ACT scores were converted to SAT scores using the SAT-ACT Concordance Tables. http://www .act.org/aap/concordance/). The students on average took 16 credit hours during the semester in which they were enrolled in the class. In the previous semester, the students' average GPA was a 2.79. The characteristics of the students are summarized in Table 1.

Students attendance before exam 1 variable, records the two labs before the 1st exam; Students attendance after exam 1 before exam 2 variable, records the four labs before the 2 nd exam, and students attendance after exam 2 but before exam 3 variable, records the four labs after the 2 nd exam but before the 3 rd exam. Table 2 gives the distribution of lab attendance. For students who attended labs before exam 1,73\% of the students attended both labs. For students who attended labs after exam 1 but before exam 2, only $38 \%$ of the students 
TABLE 6: Determinants of academic performance: (OLS) estimates with respect to the 1st midterm, 2nd, and 3rd.

\begin{tabular}{|c|c|c|c|c|c|c|}
\hline Variables & $\begin{array}{l}\text { The 1st } \\
\text { Exam }\end{array}$ & $\begin{array}{l}\text { The 2nd } \\
\text { Exam }\end{array}$ & $\begin{array}{l}\text { The 3rd } \\
\text { Exam }\end{array}$ & $\begin{array}{l}\text { The 1st } \\
\text { Exam }\end{array}$ & $\begin{array}{l}\text { The } 2 \mathrm{nd} \\
\text { Exam }\end{array}$ & $\begin{array}{l}\text { The 3rd } \\
\text { Exam }\end{array}$ \\
\hline \multirow{2}{*}{ Lab attendance before Exam 1} & 1.85 & & & 1.88 & & \\
\hline & $(1.99)$ & & & $(1.97)$ & & \\
\hline \multirow{2}{*}{$\begin{array}{l}\text { Lab attendance after Exam } 2 \text { but } \\
\text { before Exam } 3\end{array}$} & & $3.20 * * *$ & & & $3.27^{* * *}$ & \\
\hline & & $(1.01)$ & & & $(1.03)$ & \\
\hline $\begin{array}{l}\text { Lab attendance after Exam } 2 \text { but } \\
\text { before Exam } 3\end{array}$ & & & $\begin{array}{l}1.92^{* *} \\
(0.83)\end{array}$ & & & $\begin{array}{l}1.88^{* *} \\
(0.84)\end{array}$ \\
\hline \multirow{2}{*}{ Age of student } & 17.58 & -78.96 & $-88.17^{* *}$ & 16.02 & -81.95 & $-87.39^{*}$ \\
\hline & $(57.94)$ & $(56.07)$ & $(44.50)$ & $(57.46)$ & $(57.00)$ & $(45.32)$ \\
\hline \multirow{2}{*}{ Age of student squared } & -0.43 & 1.77 & $2.07 * *$ & -0.39 & 1.84 & $2.05^{*}$ \\
\hline & $(1.35)$ & $(1.31)$ & $(1.04)$ & $(1.34)$ & $(1.33)$ & $(1.06)$ \\
\hline \multirow{2}{*}{ High school grade point average } & 3.42 & 0.08 & -1.8 & 3.56 & 0.11 & -1.79 \\
\hline & $(2.77)$ & $(2.73)$ & $(2.20)$ & $(2.73)$ & $(2.75)$ & $(2.21)$ \\
\hline \multirow{2}{*}{ SAT } & $0.04^{* * *}$ & $0.05^{* * *}$ & $0.04^{* * *}$ & $0.04^{* * *}$ & $0.05^{* * *}$ & $0.04^{* * *}$ \\
\hline & $(0.01)$ & $(0.01)$ & $(0.01)$ & $(0.01)$ & $(0.01)$ & $(0.01)$ \\
\hline \multirow{2}{*}{$\begin{array}{l}\text { Previous semester grade point } \\
\text { average }\end{array}$} & $10.14^{* * *}$ & $7.14^{* * *}$ & $8.04^{* * *}$ & $10.46^{* * *}$ & $6.94^{* * *}$ & $8.13^{* * *}$ \\
\hline & (1.74) & $(1.67)$ & $(1.41)$ & $(1.73)$ & $(1.72)$ & $(1.44)$ \\
\hline \multirow{2}{*}{ Spring 2009 credit hours } & -5.55 & 2.58 & $10.19^{* *}$ & -6.65 & 2.73 & $10.08^{* *}$ \\
\hline & $(6.02)$ & $(5.97)$ & $(4.81)$ & $(5.95)$ & $(6.01)$ & $(4.85)$ \\
\hline \multirow{2}{*}{ Spring 2009 credit hours squared } & 0.16 & -0.1 & $-0.34^{* *}$ & 0.18 & -0.11 & $-0.33^{* *}$ \\
\hline & $(0.19)$ & $(0.19)$ & $(0.15)$ & $(0.19)$ & $(0.19)$ & $(0.15)$ \\
\hline \multirow{2}{*}{ Students that live on campus } & 0.14 & -1.93 & -2.28 & -0.57 & -1.78 & -2.41 \\
\hline & $(2.25)$ & $(2.24)$ & $(1.79)$ & $(2.23)$ & $(2.27)$ & $(1.82)$ \\
\hline \multirow{2}{*}{ Female students } & $-7.31^{* * *}$ & $-5.36^{* *}$ & -2.62 & $-6.95^{* * *}$ & $-5.59^{* *}$ & -2.54 \\
\hline & $(2.45)$ & $(2.40)$ & $(1.94)$ & $(2.46)$ & $(2.46)$ & $(2.01)$ \\
\hline \multirow{2}{*}{ Lab instructor A } & & & & -2.28 & 1.47 & -0.48 \\
\hline & & & & $(2.78)$ & (2.89) & $(2.32)$ \\
\hline \multirow{2}{*}{ Lab instructor B } & & & & $-6.73^{* *}$ & 1.87 & -1.14 \\
\hline & & & & $(2.74)$ & $(2.76)$ & $(2.26)$ \\
\hline \multirow{2}{*}{ Constant } & -148.67 & 841.15 & $873.97^{*}$ & -116.34 & 869.21 & $867.59^{*}$ \\
\hline & $(619.50)$ & $(601.61)$ & $(476.37)$ & (614.59) & (611.48) & $(485.10)$ \\
\hline Observations & 170 & 170 & 168 & 170 & 170 & 168 \\
\hline$R$-squared & 0.366 & 0.367 & 0.426 & 0.392 & 0.369 & 0.427 \\
\hline
\end{tabular}

Standard errors in brackets $* * * P<0.01,{ }^{* *} P<0.05,{ }^{*} P<0.1$.

attended all possible labs. For students who attended labs after exam 2 but before exam 3, 51\% of the students attended all labs. See Table 2.

There were three exams given and one final exam. Table 3 gives a summary of test performance. This study focuses on the 3 exams as the final was a departmental test. The exams consisted of 5 True and False with explanation questions and 20 multiple choice questions taken over a 50-minute period.

The homework was taken directly out of the course text; they were designed to promote outside learning and to reinforce the subject matter being taught. The quizzes again were meant to reinforce the learning material. In Table 4, the homeworks, quizzes, reports, and the in-lab activity were scored from 0 to 10 with 10 being the highest score. Most students scored poorly on the quizzes with an average of about 3.75 but scored somewhat higher on the homeworks with an average of 6.18. Table 4 gives summary statistics of the homeworks, quizzes, reports, and the in-lab activity. Again, the grading was divided into 3 sections: section 1 with 190 observations, section 2 with 188 observations, and section 3 with 186 observations.

\section{Methodology}

We want to estimate the parameters characterizing the relationship between lab attendance and exam performance. We assume that knowledge is the output of an educational production function that reflects the competition between two types of factors: student input and lab attendance input. A student input is a reflection of a number of 
individual factors, that includes ability. We assume linearity for simplicity; the relationship can be described as follows:

$$
\begin{gathered}
y_{i j}=\beta_{1 j} x_{1 i j}+\beta_{2 j} x_{2 i}+\varepsilon_{i j}, \text { where } \\
j=1,2,3 \quad i=\text { the } i \text { th student, }
\end{gathered}
$$

where $y_{i j}$ is ith students' performance on the $j$ th midterm, $x_{1 i j}$ is academic input before the $j$ th exam, $x_{2 i}$ are the student inputs, which are constant, and $\varepsilon_{i j}$ is an error term reflecting all other factors that affect learning. We measure learning by academic performance on exams, $y_{i j} \cdot x_{1 i j}$ is the measure of lab attendance, while $x_{2 i}$ includes the ordinary least squares (OLS), which are lab instructor, SAT score, high school GPA, fall 2008 term GPA, credit hours attempted in Spring 2009, age, whether the student lives on campus, and gender.

\section{Results}

From the results on Table 5, we see that lab attendance has very strong results. For instance, attending one more lab before exam 1 leads to a 4.15 point increase in exam grade, and attending one more lab before the 2nd exam leads to a 3.69 point increase in exam grade; finally, attending one more lab before the $3 \mathrm{rd}$ exam leads to a 3.36 point increase in exam grade. (We find that lab instructor does not influence performance on exam).

We find that lab attendance is positive and significant as it relates to the exam grade meaning that when students attend lab, their exam grade is higher. This is the simplest regression possible as it ignores student ability and other (OLS).

When we add in our additional (OLS) for ability and academic situation, such as credit hours, we see that lab attendance is not significant for the first exam but significant for second and third exam. We posit that lab attendance for the first exam is not significant because almost $76 \%$ of students attended both labs. There is a statistically significant increase of 3.2 points on the grade for the 2 nd exam for each lab attended. Therefore, if all four labs were attended, there was an increase of 12.8. While for the 3rd exam, the increase is 1.92 , which means a 7.68 increase if all labs are attended.

Our additional OLSs all have the expected sign. Students with higher SAT and previous semester GPA all do significant better on all tests. Even, controlling for ability, lab attendance is significant in 4 of the 6 regressions as shown in Table 6 .

\section{Discussion and Conclusions}

We report (OLS) results of two models of academic performance. The first model answers the question: does lab attendance affect exam grades? and the second model answers the question: does the lab instructor matter?

The evidence from this study provides an assessment lab attendance and academic performance. The findings suggest that the exam score was affected by absenteeism. We find that these labs give the students the same benefits as lecture attendance in smaller classes by using observations on the performance of about 200 Principles of Economics students on several tests and their attendance levels of labs.

\section{References}

[1] G. C. Durden and L. V. Ellis, "The effects of attendance on student learning in principles of economics," American Economic Review, AEA Papers and Proceedings, vol. 85, pp. 343346, 1995.

[2] S. Devadoss and J. Foltz, "Evaluation of factors influencing student class attendance and performance," American Journal of Agricultural Economics, vol. 78, no. 3, pp. 499-507, 1996.

[3] D. Romer, "Do students go to class? Should they?" Journal of Economic Perspectives, vol. 7, no. 3, pp. 167-174, 1993.

[4] L. Stanca, "The effects of attendance on academic performance: panel data evidence for introductory microeconomics," Journal of Economic Education, vol. 37, no. 3, pp. 251-266, 2006.

[5] D. R. Marburger, "Does mandatory attendance improve student performance?" Journal of Economic Education, vol. 37, no. 2, pp. 148-155, 2006.

[6] C. Dobkin, R. Gil, and J. Marion, "Skipping class in college and exam performance: evidence from a regression discontinuity classroom experiment," Economics of Education Review, vol. 29, no. 4 , pp. 566-575, 2010.

[7] D. R. Marburger, "Absenteeism and undergraduate exam performance," Journal of Economic Education, vol. 32, no. 2, pp. 99-109, 2001.

[8] Jennjou Chen, Tsui-Fang Lin, and J. Marion, "Class attendance and exam performance: a randomized experiment," Journal of Economic Education, vol. 39, no. 3, pp. 213-227, 2008.

[9] J. W. Hollister, "General chemistry workshop attendance and improved student performance," Journal of Chemical Educcttion, vol. 70, no. 12, pp. 1013-1015, 1993. 

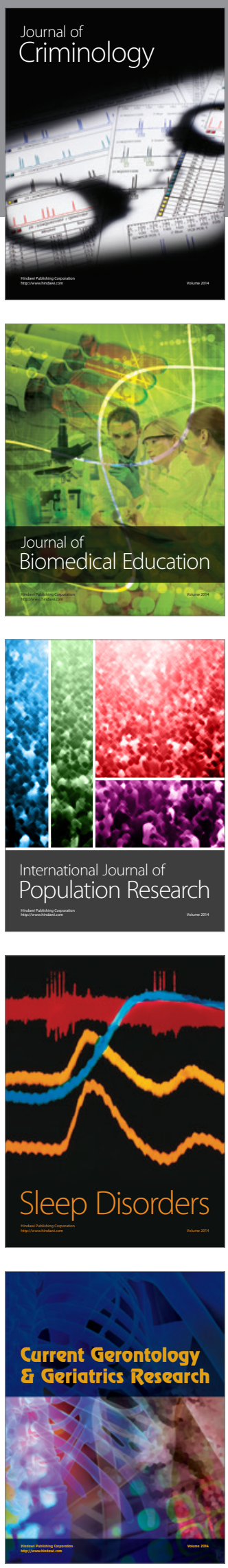
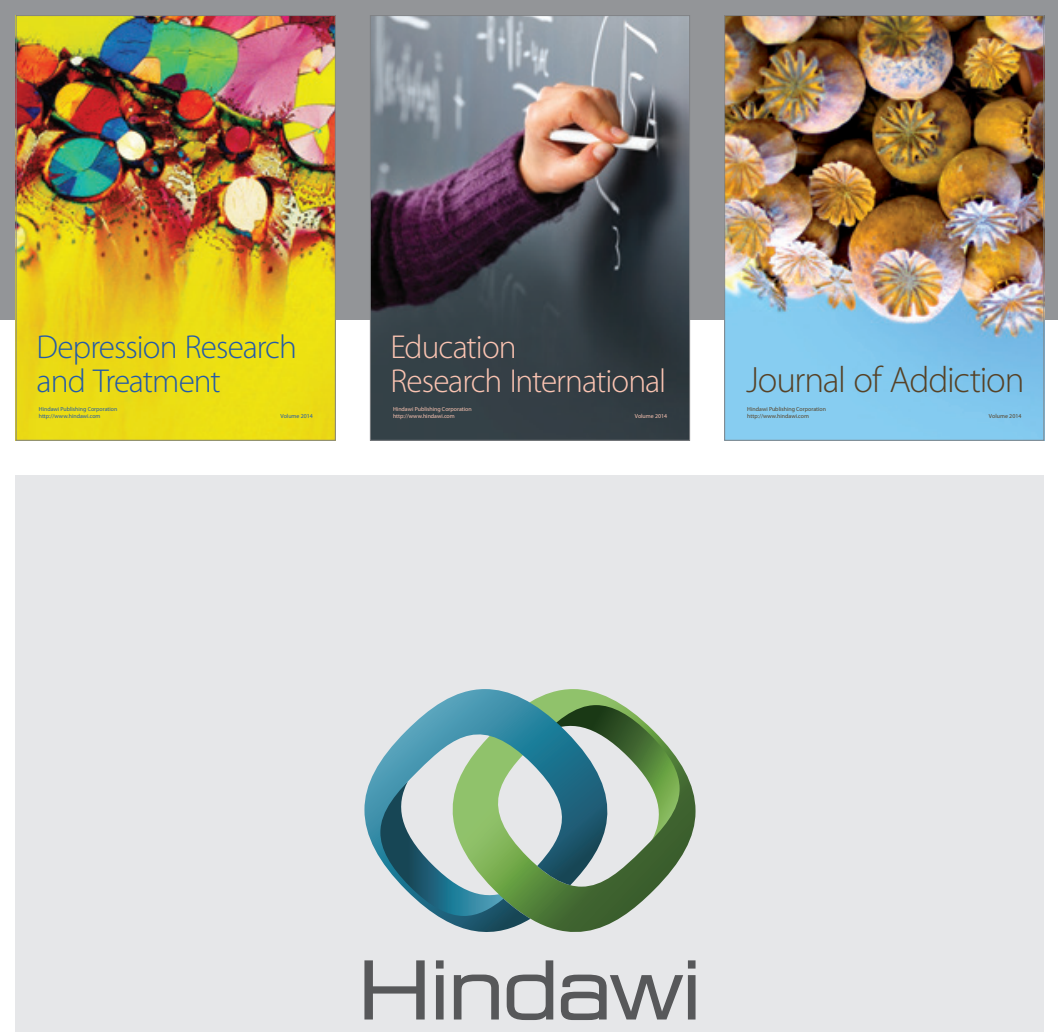

Submit your manuscripts at

http://www.hindawi.com

Child Development Research
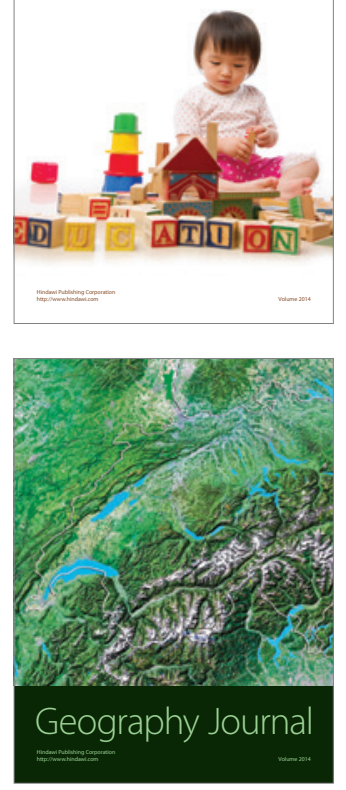

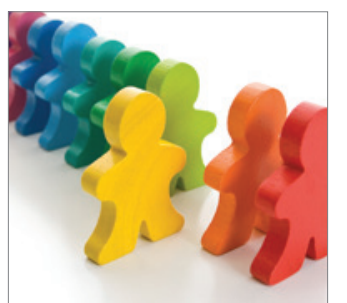

Autism

Research and Treatment
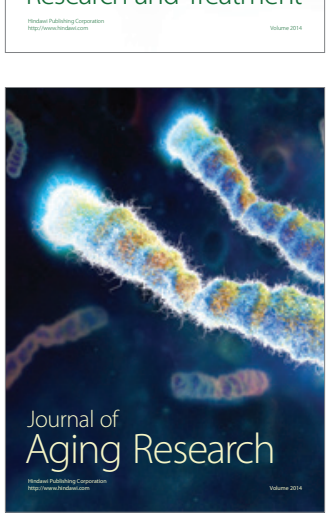
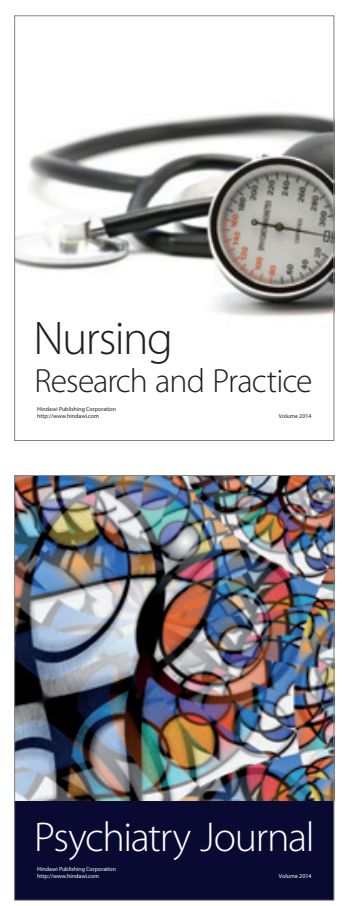
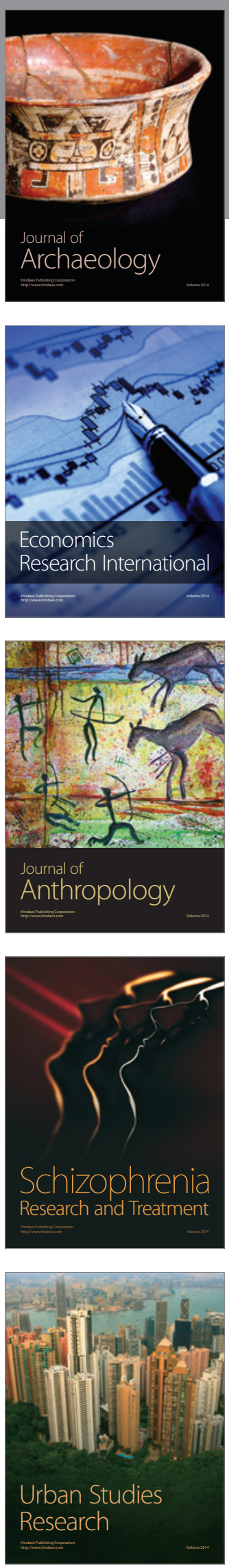